\title{
Establishment of Multidisciplinary Methodology in the Modern Industrial Enterprise Management
}

\author{
Elena Dergacheva ${ }^{1, a}$ \\ ${ }^{1}$ Bryansk State Technical University, 24103550 let Oktyabrya Boulevard 7, Bryansk, Russia
}

\begin{abstract}
The concept of an enterprise as a socio-technical system meets a wide socio-economic approach in the management of the economic complex. In accordance with this approach, a company as a product of the society develops on the basis of socio-economic patterns, supported by scientific and technical solutions. And the surrounding nature evolves on the basis of natural biological laws that does not imply interwoven links of these processes. From the field of view of researchers and managers due to the activities of the company, the deep transformation of interconnected society and nature escapes through the use of advanced productive forces, the expansion of the artificial world as a whole. Social systems recreate the technical infrastructure of an enterprise and in the wider build artificial environment the technosphere. It helps to accelerate the innovative development of the enterprise, and also leads to the interrelated transformations in a society, a person and nature. Therefore it is necessary to expand the narrow content of the broad multidisciplinary system approach with its interpretation, to include integrative technogenic socio-natural processes into the consideration of enterprise systems. This will allow preventing negative trends and in the future - coming over to the sustainable socio-natural development.
\end{abstract}

\section{Introduction}

In the most general form a modern industrial company is a multifunctional complex, which includes social and technical systems. The idea of a company as a purely socio-technical system fits within a narrow socioeconomic approach in the economic complex management. Under this approach, a company is considered as a sustainable system, which sets the external socio-economic relationships with other organizations and interacts with its environment - the natural environment (biosphere). It is assumed that a company as a product of the society develops on the basis of socio-economic patterns, supported by scientific and technical solutions, and the nature evolves on the basis of natural biological laws that does not imply interwoven links between these processes. Thus, a company is not considered as a part of the complex system and technologically evolving social and natural world. From the field of view of researchers and managers due to the activities of the company the deep transformation of interconnected society and nature escapes through the use of advanced productive forces, the expansion of the technosphere and the artificial world as a whole. This narrow approach to

\footnotetext{
${ }^{\mathrm{a}}$ Corresponding author: eadergacheva2013@yandex.ru
}

understanding industrial enterprise limits its ability to manage effectively its current and future sustainable development. It is therefore necessary to supplement the narrow socio-economic methodology for management activities with its broader interpretation to predict the consequences of socio-technical systems in terms of social, technical and natural interactions and changes.

\section{Results}

Social and technical systems of modern enterprises are in a complex interaction with each other and with the environment. The company staff at different levels of the hierarchy of management and involvement in the production process is referred to social systems. Social systems with the help of science and technology of the productive forces recreate the technical and technological infrastructure (system) of a company, and in a broader sense - the technosphere. The latter is an artificial inanimate nature (the environment). Its components are man-made objects (means of production, industrial complexes, cities, buildings, artificial nonbiospheric technologies), synthetic chemicals, artificial electromagnetic fields formed due to emerging economic 
transformation of the society objects of natural and artificial nature $[1,2]$. It is important to note that at first the invention of technics and then its accelerating development at the beginning of the XXI century has reached such a level that the establishment of the technosphere although promotes innovative development of a company, but it leads to the inevitable transformations in a society, a person and nature, in the framework of which the company and its built environment exist. That is why the management of modern enterprises leads to man-triggered socio-natural (socio-techno-natural) processes, which are characterized by close interaction between technosphere, sociosphere and the biosphere [3]. These elements make significant impact on each other, as evidenced by the historical stages of industrial development. These factors must be considered when developing a methodology for industrial systems management.

\section{Discussion}

During the transition to an industrial economy about three centuries ago on the "wave" of the achievements of the Industrial Revolution (XVIII-XIX centuries.) The company is beginning to create machine technology and artificial technology that replace manual labour more efficient, improve productivity and better serve the growing necessities of life population. Together, machine technology and rapidly developing science create conditions for the establishment of social scientific and technological productive forces, and on their basis - the real artificial inanimate, object-gun, information and communication and electromagnetic environment of life - the technosphere. Such social changes contribute to the transition of agricultural societies on the path of market development of industrial and man-made with the establishment of corresponding infrastructure. Subsequently, with the deployment of scientific and technological revolution (from the middle of the twentieth century) and sophistication of the technosphere the signs peculiar to the post-industrial stage of development of social and technogenic development are formed mainly in industrialized societies. Socially formed technosphere of enterprises exists within the boundaries of the biosphere and becomes one of the determining factors of social and socio-techno-natural development.

Pre-industrial-technogenic (XIV-XVIII cent.), industrial-technogenic (from the end of XVIII c.) and postindustrial-technogenic (from 50th years of $\mathrm{XX}$ century) modernizations make up the periods in the development of the technogenic era and modern company management systems.

At the stage of pre-industrial-technogenic modernization in Western Europe occured slow transition from agricultural and handcrafted productions to manufactural (i.e. pre-industrial). The development processes of urbanization started, i.e. concentration of non-biospheric technologies, manufactures and population in urban environment. In the originating production (technosphere) the incoming material and energy streams were formed from substances of biospheric (for example, tree fuel, coal) and predominantly non-biospheric origin (erg, mineral resources of non-biospheric origin - metal ore, mountain breed), and the outcoming materials represented industrial products and production wastes of an artificial nature. As a result of the exchange between technosphere and biosphere the latter, although in minor quantities, got substances of artificial origin, which pollute biosphere. This fact facilitated origination of technogenic nature changing processes. Pollution of natural ecosystems led to the extension of technosphere (including increasing its controlling actions), gradual reduction of environment regulating functions and spaces of the biosphere. So, the transition to fossil fuel (coal) firing in London caused such a phenomenon of environment pollution as smog, which resulted in the spreading of pulmonary diseases and became a reason of untimely death of people with weak health, and flexible biosphere could not restore a disturbed ecological balance. The equipment of that period of time was powerless to "correct" the defects of progress (and at the same time to satisfy protests of separate enthusiasts against "smoke"), the improvements most often concerned changes in kinds of fuel and sites of industrial production. Also technogenic complication of socio-economic and socio-natural development was determined by establishing of scientific and technical labour forces and development of artificial processes, realized in new spheres of an economic management industry.

Therefore, at the stage of pre-industrial and technogenic modernization the globalizing society began establishing links between originally independent systems (biosphere and the technosphere) and constructing an artificial world. Man-made changes in natural processes were local (i.e. were implemented in some countries), however, during this period the foundations of world processes (urbanization, industrialization, tehnospherization) were created, which together marked the beginning of the establishment of industrial enterprise management systems and the development of artificial environment for their activities.

At the second, industrial and technogenic stage of modernization and development of globalization a revolutionary shift from the manufacturing to a factory production is committed, which leads to the establishment of the industrial and urban mode of production, at first in England and later in other countries. Growing market dictated the need for further expansion of the industry, strengthening the links between the objects of the technosphere, establishing a distribution network in different countries, that is, the development of the activities of transnational corporations. At that, the agrarian sphere was not affected by industrialization.

Produceability understood as a method of production from raw material extraction to its subsequent processing, producing and sales, became the basis for the establishment of a global model of integrative relations in the world economy, the expansion of social and technogenic development and its technosphere. As a result, in the twentieth century it formed a planetary 
industrial and technogenic zone in the northern hemisphere, stretching from the United States - across Europe - to Japan, focusing the global consumption of natural resources and their transportation routes servicing them. On their territories, as a result of activity of the enterprises there were changes in society and developing system of social and natural life. On either side of it to the north and south, there are global commodity belts. Specialty of regions of the world (as the industrial-technological and servicing) determined their place in the emerging international division of labour, as the international scientific and technical forces of production related to the functioning of the technosphere, located in the global industrial and technogenic zone - in the industrial and urban environments and serving the technosphere units, which were traditionally at the agricultural-development stage in two world commodity zones. Between the countries involved into the world economy there were tied trade relations, the export of capital began growing. This not just enhanced the process of internationalization of economic life, but also was accompanied by the expansion of technological transformation of natural processes. So, on the basis of the establishment of the international division of labour and international productive forces there was realized the global process of drawing societies, which were at different levels of development, into the modern technological era.

In England, France, Italy and North America the formation of industrial capitalist systems took place during the natural historical development, regular technogenesis. In the countries with strong traditional mentality, such as Germany, Russia and Japan there was carried out purposeful state policy of industrial modernization and stimulation of industry development in towns which gave them a possibility by already the beginning of the XX-th century to come down into the number of industrial states and to become the hubs of world industrial man-caused belt. The reformist way of capitalist development and technogenesis became apparent in the slow transformation of land relations into commodity ones because of the conservation of patriarchal forms in the agriculture organization and shortage in capitalist savings.

In the first half of the twentieth century, the risk of environmental crisis obviously was not perceived by humanity, as man-made technogenic changes in natural processes occured without signs of large-scale destruction of ecosystems. Cities as centres of concentration of the industry were pairing nodes of universalizing industrial and man-made belt. Black impregnations on buildings in cities, dirty curtains in flats close to industrial enterprises, black foliage on trees, suppressed flora - all these features of air pollution with smoke (as a main atmospheric pollutant of that time). More than this, the coloration of white butterflies did not ensure them a possibility for masking against birds of prey on darkened foliage of trees, that is why white individuals were forced out by dark forms. The technosphere was created by means of industry sprawling, displacement of natural ecosystems and still poorly defined processes of man-made changes in the nature.

So, at the stage of industrial and man-made modernization, the socio-economic and technicaltechnological structure of Western Europe, North America, Russia and Japan changed, thus the transition from local to global expanding industrial transformation of natural processes was made. Universalization of the industrial mode of production in these countries was accompanied by employment growth in the industry, which meant relative isolation from the biosphere technology and turn to non-biospheric, artificial technologies.

Transition to the third stage of post-industrial and technogenic modernization and globalization started in the middle of the twentieth century. From the period of scientific and technological revolution without the use of science the further development of non-biosphere and improvement of biosphere technology became difficult. Possibilities of continuous acceleration of technological development, business and profits growth were associated with advances in science. This resulted in the beginning of an exponential growth of technosphere facilities and its constituent artificially synthesized chemicals. Non-biosphere technology has penetrated into agriculture, that corresponded to its processes of industrialization and intensive man-made changes in the nature within the industrial societies. Such large-scale intervention by the society and the technosphere led to the fact that changes in the biosphere became irreversible, because the depleting ecosystems were not restored.

The establishment of a post-industrial economy and the strengthening of scientific and technological development of society in the industrialized western capitalist countries marked a shift in the emphasis in their economies from the industry to the sphere of hightech services and high technologies, which affected the peculiarities of cross-country division of labour and business management. As the demand for agricultural products and raw materials sector has become relatively reduced, and for the industry products (especially machinery and chemical) it has increased, the crossindustry exchange of goods production and processing industries was falling and the intra-exchange (i.e. the connection of the country to the individual stages of the production cycle products) increased. Therefore, the developing countries involved in the integration process, got an opportunity to go to an accelerated version of the industrial development with its attendant man-made changes in the nature. But, unequal technical and economic potentialities defining a dissymmetry in the international exchange and lack of development in technosphere in many respects conditioned on social and economic developmental lagging of these countries. In such away, a world polarization with limited potential of the model of the industrial "overtaking" development in spite of scientific-engineering borrowings and national resource mobilization was strengthened.

From the period of information and communication revolution (1970) the processes of informatization of enterprises (with a concomitant improvement in 
transport) allowed establishing a close supply-side relationships between the various societies and expanded the number of countries within the global industrial and technogenic belt due of Southeast Asia and South America countries. All this formed the planetary unity of technological processes of the technosphere, tailored to the needs of the market. According to environmentalists, over the past century the area of technosphere increased threefold due to consolidation of the industry, the annual increase in the hundreds of times of the production of synthetic compounds, which was accompanied by the degradation of biosphere of the fifth of the land [4].

Another biotechnology revolution (1980) marked the beginning of the technological manipulations with the natural and biological objects, i.e. the production of technologically modified biosphere organisms (transgenic organisms). It corresponded to the deepening of processes in man-caused changes of nature, dissemination of science intensive techniques in agriculture and agricultural business of trans-national corporations. The society began to reproduce technogenity in the form of the biological life creation purposefully, that is, not only at the level of manufacturing engineering work-pieces and associated it changes in nature. Globally, transnational corporations (as they are the main developers) go to commercial use of biotechnology and nanotechnology. This creates a basis for the modern enterprise management - a technogenic economic organism, qualitatively transforming the nature. This statement gets even more compelling, if considering it in the beginning of the XXI century on the "wave" of nanotechnology revolution, when the centre of technological activity shifted from the microcosm of information technology into the nanoworld with a purpose of controlling physical, chemical and biological properties of systems, intermediate in size between individual atoms and molecules.

Now comes the improvement of the technological base of industry and building of synergetic potential of the various technologies (NBIC, nano-, bio-, info- and cognitive converged technologies). The dynamic properties of the social and natural reality transformed by economic society and technosphere confirm the importance of using a synergistic method. On the basis of this method the integrative technological processes are considered as non-linear and explosive, leading in the long term to the complex rebuilding of socio-natural world and even to changes in the character of life evolution on the planet from the natural (biospheric) to the technogenic one in many respects artificial (even post-biospheric) [5] as a result of the management activities of economic entities. Such changes should be considered in the management of a modern enterprise, which also makes it necessary to use the methodology of the system approach. This approach should be expanded by considering the relationship of social, technospheric and natural transformation processes and laws.
Global processes and challenges unfolding in the last two or three centuries of technogenic socio-natural development, have not yet been deeply studied by social and economic, technical and natural sciences, which does not allow covering all spheres of activity of the modern enterprises management. The technogenic world is formed on the basis of the objective and subjective changes relatively the "core" of the industrial society and transnational corporations, on which other societies depend. Large-scale processes of integration of social, technospheric and transformed natural systems into a coherent whole are becoming information-coordinated, technically and technologically feasible and commercially profitable in a relatively short time. All this testifies to the fact that it is a multidisciplinary approach to the management of a modern enterprise, which will allow taking a consistent look at its operation with a view to comprehensive consideration and prediction of the consequences of its activities, warning of negative trends and the transition to sustainable socionatural development, as well as the establishment of appropriate educational technology.

The active study of these processes has been done by Bryansk scientific and philosophical school of sociotechno-natural processes and social-technogenic development of the world [5-7], and also by a sector of bio-philosophy of the Institute of Philosophy of the Russian Academy of Sciences. This scientific school considers socio-natural development in the conjunction with social, artificial and nature-biological changes and offers a new paradigm of researches of processes in the society and economy. The origins of such a comprehension of current social development and economic processes in economy go back to the analysis of peculiarities in the formation and development of technogenic (industrial and post-industrial) society, its core characteristics, negative effects upon biosphere nature and a person, which is presented in the works of the scientists of the school. These integrative processes must be taken into account in the modern enterprise management, as the matter concerns evolutional changes in the society and nature as a result of economic activity.

\section{References}

1. E.A. Dergacheva, Technogenic society and contradictory nature of its rationality (Bryansk, Publishing House of BSTU, 2005)

2. N.V. Popkova, Philosophy of the technosphere (Moscow, Librokom, 2007)

3. E.A. Dergacheva, Trends and prospects in sociotechno-natural globalization (Moscow, Librokom, 2009)

4. T.A. Akimova, A.P. Kuzmin, V.V. Khaskin, Ecology. Nature - Man- Technics (Moscow, Economy, 2007)

5. E.S. Demidenko, E.A. Dergacheva, N.V. Popkova, Philosophy of world socio-technogenic development: papers, concepts, terms (Moscow, World Inform-Encyclopedia, Bryansk, BSTU, 2011)

\section{Conclusion}


6. S.N. Chuvin, Sotsiologicheskie issledovaniya 1, 150-152 (2007)

7. N.N. Lapchenko, Herald Baltic Federal University named after I. Kant. Humanitarian sciences 6, 53-61 (2009) 